\title{
Two new species of Cerapus from Samoa and Fiji (Crustacea: Amphipoda: Ischyroceridae).
}

\author{
J.K. LOWRY, \\ The Australian Museum, P.O. Box A285, Sydney South, NSW 2000, Australia.
}

\begin{abstract}
Cerapus oceanicus and C. pacificus are described from Samoa and Fiji. They are distinguished from other species in the Cerapus group mainly on the morphology of the second gnathopods. A discussion of genera in the Cerapus group indicates that Runanga and Baracuma may be based on gradational characters.
\end{abstract}

Lowry, J.K., 1985. Two new species of Cerapus from Samoa and Fiji (Crustacea: Amphipoda: Ischyroceridae). Records of the Australian Museum 36: 157-168.

Keywords: Amphipoda, Ischyroceridae, Cerapus, west-Pacific, taxonomy.

There are now three closely related genera in the Cerapus group: Cerapus Say (1817), Runanga Barnard (1961) and Baracuma Barnard \& Drummond (1982). These genera are extremely similar in morphology and share several highly apomorphic characters, particularly peraeopod 5, uropods 1 to 3 and the telson. As Barnard \& Drummond (1982) pointed out, an unequivocal diagnosis of Cerapus is difficult because the type specimen of $C$. tubularis Say (type-species of the genus) is lost. Runanga was established for species with a scalelike accessory flagellum and progressively reduced pleopods. The male has never been described. Baracuma was established for species with irregularly shaped coxae 1 to 4 , apically narrowed and poorly cleft telson, an elongate fifth peraeonite and coxa in adult females and a ventral keel on peraeonite 2 in adult males.

Some of the characters used to distinguish Runanga and Baracuma appear to be gradational. The elongation of the fifth peraeonite and coxa in adult females also occurs in Runanga coxalis Barnard, Cerapus benthophilis Thomas \& Heard, and both species described here. The shape of the telson in $C$. benthophilus and B. alquirta Barnard \& Drummond is very similar, but the cleft is deeper in $C$. benthophilus. In the new species described here both have apically narrowed telsons but one is notched and the other is cleft to the base. All of these species have some degree of progressively reduced pleopods and all have some degree of irregularly shaped coxae 1 to 4 . The peculiar antennal character mentioned by Barnard \& Drummond (1982) to distinguish $C$. crassicornis Bate from Baracuma helps to define a coldwater group of Cerapus species discussed by Lowry (1981).

Runanga is thus distinguished by its vestigial accessory flagellum and Baracuma by the ventral keel on peraeonite 2 of the adult male. The new species described here have neither of these characters. I am therefore placing them in the broadly defined genus Cerapus. There are many Cerapus-like species in the South Pacific and Indian Oceans awaiting description. Their description will probably help to make generic definitions much clearer.

\section{Cerapus oceanicus n.sp.}

Figs 1-5

Type material. HoLOTYPe, male, $6.1 \mathrm{~mm}$ AM P34734; allotype, $5.3 \mathrm{~mm}$, AM P34735; 13 males, 15 females and juvenile paratypes AM P34736-P34740; Apia, Upolu, Western Samoa, $13^{\circ} 48^{\prime} \mathrm{S} 171^{\circ} 44^{\prime} \mathrm{W}$, collected in the lagoon, living on the seagrass, Halodule sp., $0.5 \mathrm{~m}$ depth, A.A. Myers.

Diagnosis. Rostrum acute, $1 / 3$ length of peduncular article 1 . Gnathopod 2 of adult male, palm of article 5 with an inner tooth, article 5 twice as long as broad and slightly expanded posterodistally, dactyl crenulate along posterior margin. Coxa 3 with sinusoid anteroventral margin. Coxa 4 with a subquadrate lobe anteriorly. Peraeopod 4, article 2 as long as articles 3 to 7 combined. Peraeopod 6, setae on posterodistal corner of article 5 longer than articles 6 and 7 combined. Peraeopod 7, elongate setae on antero- and posterodistal corners of article 5. Telson cleft to base.

Description. Holotype male, $6.1 \mathrm{~mm}$. Head: rostrum acute, elongate, about $1 / 3$ length of peduncular article 1; lateral cephalic lobes with subacute anteroventral corners. Body elongate, cylindrical, mottled brown throughout, peraeonites 5 and 6 longest, subequal in length.

Antenna 1 well developed, setose, about $1 / 2$ length of body; peduncular articles 1 and 2 subequal in length and slightly shorter than article 3 , article 1 expanded 